\title{
The analyses of open and distance education to promote rural education fair in the vision of Urbanization
}

\author{
Wang Junfeng \\ Distance Education Research Center of Shaanxi Province \\ Shaanxi Province, Xi'an ,China \\ wangjynfeng@sina.com
}

\begin{abstract}
The urbanization construction faced with the household registration system, the allocation of resources, human development, and other key issues, there is a need for a large number of know the countryside, familiar with the countryside, have a certain skill talent team, and at present there are some problems in vast rural areas such as widespread seriously quantity insufficient of talent team, age structure aging, information knowledge update slow, all these problems hindering the development of urbanization. Open and distance education can cultivate talents needed for urbanization construction, reduce urban and rural education gap and promote education fair.
\end{abstract}

Keywords-urbanization; Open and distance education; Education fair

\section{INTRODUCTION}

The 18th CPC National Congress propose that,to speed up the perfect of urban and rural integration development system and mechanism, focus on the urban and rural planning, infrastructure, public services and others to promote the urban and rural elements equal exchange and public resources equilibrium configuration, in order to the form a new type relationship of industry promote agriculture, the country led by city, workers and peasants reciprocity, urban and rural as an organic whole. [1] The realization of the grand goal, need a large number talent team who are know the countryside, familiar with the countryside and who have certain skills, but currently the vast rural areas has the problem of a widespread talent team quantity seriously insufficient, age structure aging, information and knowledge update slow and other problems hinder the rapid development of urbanization. How will the existing rural surplus labor force into new citizens with a skill of the new town, is and urgent and reality problem in front of government in all levels.

Modern open and distance education is a new type of education form produced along with the development of the modern information technology, it is main means to build lifelong learning system for the people of intellectual economy times. The outstanding features of modern open and distance education are: there is really no restriction of space and time; the education object expand to whole society; have more abundant teaching resources for suffering pedagogue; teaching form from the original in order to teach change to in order to learn [2].

RTUV since more than thirty years, always adhere the managerial guiding ideology of "to grass-roots, facing the industry, facing to the countryside, facing the remote and national area", set up 44 provincial RTUV, 1103 city-level RTUV branch, 1853 county level RTUV workstation, forming a national urban and rural distance education network system. Especially in April 1999,since the ministry of education decided to implement "the central RTUV intelligent cultivation model reform and open education pilot project", namely open education project , RTUV into the rapid development stage, in 2010 statistics show that open education has 2796047 internal student [3].

Urbanization talent demand urgency, Radio and Television University (RTUV) education idea, the applicability of the mode of running school, which makes the distance open education, can bear the majority of the responsibility in the process of train practical talents for urbanization of rural.

\section{THE MAIN PROBLEM OF PRESENT COUNTRYSIDE URBANIZATION DEVELOPING}

Although the urbanization construction has a lot of problems, but we think that the main problem is the household registration system, the social resources allocation, human development, etc.

\section{A. the household registration system}

China's current census register system based on land as the core of the rural household registration system and identity is closely related to the treatment of urban household registration system, it formed our social unique binary system structure, greatly hindered the urban and rural integration, personnel free flow and the further development of economy and society. At the same time, because the existence of congenital identity difference, which makes the citizens' equal rights in the reality cannot be achieved [4].

\section{B. Resource allocation}

The national bureau of statistics Shaanxi NBS survey office released the data yesterday shows that, In 2012, Shaanxi urban per capita disposable income rose to 20734 Yuan, a year-on-year increase of $13.6 \%$, after deducting the price factor, the actual growth $10.8 \%$; Rural per capita net income of 5763 Yuan, a year-on-year increase of 14.6\%, after deducting the price factor, the actual growth $11.2 \%$ [5]. Urban per capita disposable income in rural residents' per capita disposable income 3.6 times [6] such as table 1 shows. 
TABLE 1 SHAANXI URBAN PER CAPITA DISPOSABLE INCOME AND RURAL PER CAPITA NET INCOME RATIO

\begin{tabular}{|c|c|c|c|c|c|c|c|c|}
\hline Year & $\mathbf{2 0 1 2}$ & $\mathbf{2 0 1 1}$ & $\mathbf{2 0 1 0}$ & $\mathbf{2 0 0 9}$ & $\mathbf{2 0 0 8}$ & $\mathbf{2 0 0 7}$ & $\mathbf{2 0 0 6}$ & $\mathbf{2 0 0 5}$ \\
\hline $\begin{array}{c}\text { Town/farmers' } \\
\text { income ratio }\end{array}$ & 3.6 & 3.63 & 3.82 & 4.11 & 4.1 & 4.07 & 4.32 & 4.03 \\
\hline
\end{tabular}

Not only he average net income of farmers is a quarter of the city worker, but also the farmers from the countryside into the cities and towns, because of the present household registration system has long restricted, farmers in the city compared with urban residents always are disadvantage in education training, medical and health, social resource allocation and possession, social security and other closely related to the household registration system, so difficult to became a true sense of citizens. China's social structure is step by step change from the previous "binary" structure to now "ternary" structure increased a group of migrant workers between in the traditional sense of farmers and citizens these two groups. Migrant workers separated from the first industry and come into city in the second and third industries , they are neither the real farmers, because they have been away from the agricultural production activities; the more is not realistic significance of the citizen, because they are not fully integrated into the city life, also is not assimilate by the city civilization. Residents of cities, urban migrant workers and the peasants these three parts in the social structure of social resources possession and distribution as shown in table 2 [7]

\begin{tabular}{|c|c|c|c|}
\hline & Urban residents & Migrant workers & Farmers \\
\hline Employment & Diversity & $\begin{array}{l}\text { Dirty, tired, bitter, insurance } \\
\text { industry }\end{array}$ & The first industry \\
\hline Income level & High or higher & Low or lower & Low or lower \\
\hline Unemployment & Yes & No & No \\
\hline Labor safeguard & Yes & No & No \\
\hline Retirement & Social retirement & Family provision & Family provision \\
\hline Housing & Buy commercial houses & Rent & Built \\
\hline Medical & $\begin{array}{l}\text { Medical treatment or health } \\
\text { care }\end{array}$ & Pay by themselves & Pay by themselves \\
\hline Education & No extra cost & Yes & No extra cost \\
\hline
\end{tabular}

At the beginning of the state founding, our country in order to realize industrialization and economic development as soon as possible, taken primitive accumulation from rural areas to carry out the practice of urban development, this is the necessary to change the face of be poor and blank, save the economic collapse of new china. But with the development of economy, there is no big change in social resource allocation tendency city policy in our country, although in recent years China implement the agricultural tax relief, to develop the new rural construction, the cooperative medical and other activities, but it is not involved in education, household registration, pension, employment level of social resource allocation reform, and in some ways, the gap between urban and rural areas are still growing.

\section{Human development}

At the early beginning of reform and opening up, the education implement from primary school to college have set up their key school, the corresponding such as good teachers, financial allocation to the key school tilt, The allocation of resources in education on the similar to the 
founding of the economic development way, the most outstanding performance in scramble for the best teachers : Small city for the advantage of small towns education resources, medium-sized city for the advantages of small city education resources, big cities use turn registered permanent residence, distribution housing, solve the spouses and children work etc. preferential terms, from small and medium-sized city "dig" the good teachers. After years plunder, make plenty of rural prominent teacher teachers , this valuable social resources ,are concentrated in the city, together with all kinds of key school are concentrated in the city, make broad rural education development and the development of the people is greatly limited.

According to Todaro population flow model, The rural labor force decide transfer to the city's it does not depend on the actual income difference between urban and rural areas, but the income of urban and rural expected difference, at the same time, education degree is the key factors to influence people expected income judgment and measure , The rural residents by education degree is higher, the transfer to the city of expected income is higher, therefore, the likelihood of migration is greater. But at present in China, the reality is the rural population is a serious shortage of education degree, the education quality obviously lag behind, even if they don't be projected income the factors that influence the restriction into town, is unlikely to work and life in the urban areas for a long time, because along with the social productive forces progress and development, people from all walks of life to the employee's labor quality and labor skills also more and more high, so low quality of the labor market will be eliminated [8]. Therefore, the urbanization construction, must consider the development of the rural people.

These problems are the main problems in urbanization, but solve the above problem, on the one hand, need the support of national policy, on the other hand, a large number of rural needs more talents to promote the solution of these problems. Therefore, in the urbanization construction personnel training problem is particularly prominent.

These problems are the main part blocked the urbanization construction, but solve the above problem, on the one hand, need the support of national policy, on the other hand, a large number of talents needed in rural to promote the solution of these problems. The formulation and implementation of policy need talents to achieve, therefore, in the urbanization construction personnel training problem is particularly prominent.

\section{THE ANALYSIS OF OPEN AND DISTANCE EDUCATION AND THE NEW RURAL CONSTRUCTION}

Open and distance education can provide personnel support for urbanization; can make high quality education resources sharing between urban and rural areas, narrow the gap between urban and rural areas; The rapid development of information technology for open and distance education carried out in the vast rural areas to provide security.

\section{A. Urbanization is the core of urbanization, open and distance education can provide for urbanization construction talent guarantee.}

Development rural economy talents are especially important. The state founding more than sixty years the center of gravity of China's political and economic development is tilt to city, rural actually become a cheap Labor provider and cheap production data provider in urban development. Especially since the reform and opening up, the relevant system design makes the best talent flow becomes possible and it gradually formed a village, town, county, city, province talent at all levels of the cascade flow up phenomenon. Talent unidirectional flow makes a large number of outflow of rural talent, in addition, pesticides, seeds, and fertilizer prices continue to rise, the added value of agricultural production decreases year by year, at home sow the land without profit, many young and middle-aged labor to leave home, go to the southeast coastal city, the lack of talents working situation in the countryside is more outstanding. So the town construction first need to build a known rural economic development law, familiar with the local rural folk culture, long-term development perspective and can take root rural talent team.

MIIT department data show that in 2012 from January to November, the Internet broadband access < http://www.cww.net.cn/techClass0 > users have a net increase of 24.027 million for a total of 174 million users. Mobile Internet users have a net increase of 111 million for a total of 750 million users [9]. A surge of mobile users for open education in rural areas, and provide technology and hardware support.

Open education can make full use of the existing teaching platform and telecommunications and cooperate with mobile company, on the one hand, will integrate the existing teaching content, optimization, and upgrade the teaching platform, make it suitable for smart phones, including a variety mobile equipment; On the other hand, to put into practice to include the compulsory education, elementary education, vocational education and so on various stages of education "open" education, attracting similar Netease open class provides a variety of high quality teaching resources at home and abroad, and all free all open, make broad rural learners of all ages really experience open education teaching ideas of "everyone can learn to learn is always can learn", training talents for urbanization construction , in order to offer talented personnel. 
B. The purpose of the urbanization is gradually eliminate the dual social structure of urban and rural, eliminate the gap between urban and rural areas, open and distance education can make up for the difference between the urban and the rural education, to realize the quality education resource sharing, and promote between the urban and the rural education fair.

Education fair is the most fundamental and most important social fair [10]. Between the city and countryside binary system social structure, urban and rural gap should eliminate from start to realize urban and rural education fair. Education unfair reflected in three different levels: education chance, process and the result unfair.

Open education can provide the same for both urban and rural residents by the education opportunities. Open education on the one hand, the education network all over the country can provide for urban and rural residents with the same quality teaching service, no family background, educators identity requirements; On the other hand the intelligent mobile phone as a representative of a new generation of mobile communications equipment popularization, makes the Internet anytime, anywhere learning gradually integrated into urban and rural residents' daily life, urban and rural residents learning opportunities through the open education to realize equality.

Open education for each learners provide same resources, such as the best teachers lecture resources are uploaded to the video server, urban and rural students can watch online, school education, online tutoring questioning and answering, the final exam and other teaching links all through the network implementation, requirements are consistent, minimize the human factors of interference, and to ensure the urban and rural students in the learning process of the fair.

Open education in the learning outcome is equal, the final exam evaluation link requirements are the national unity, there is no difference of all interval Students get graduation certificate and degree files in the national is unified.

\section{The rapid development of information technology, change the rural life and learning style.}

The popularization of intelligent mobile phone rapid accelerates the process of change. like the country people was used to watching TV and listening to the radio to get to know the weather conditions, and subject to the fixed time limit, and now through the intelligent mobile Internet at any time can query the future 7 days weather conditions; Be like again, before the farmland have diseases and insect pests occurrence, people often resorting to agricultural agent, and now resorting to network to solve the problem.

At the same time, along with the new cycle of gradual change mobile phone is short, the growing competition, all kinds of $3 \mathrm{~g}$ smartphone price also gradually reduced, the general public basic can accept. This is clear the obstacle of the hardware equipment of open education development, learners can learn without specialized to buy expensive computer.

Moreover, e-commerce and other network business activities has become increasingly active, also makes more and more rural people to join the army of online transactions, e-commerce eliminates the obstacles of use intelligent mobile access internet, it can be said that is a popular online class, at the same time also has the Internet learning ability, for the open education smoothly laid a foundation.

\section{OPEN AND DISTANCE EDUCATION TO PROMOTE EDUCATION FAIR STRATEGY BETWEEN THE URBAN AND THE RURAL}

Open and distance education has been carried out through the plan "one undergraduate in one village " in our countryside, but in terms of scale and depth, there is very big difference with we expect to, need further improve relevant policies, improve open education itself construction measures to promote between the urban and the rural education fair, as soon as possible.

A. From the national level to formulating relevant policy, encouraging the use of open and distance education to improve urban and rural education level, narrow education gap.

One is to increase investment. The state should formulate relevant policy, strengthen the investment of open education ,put improve and enhance rural education quality at the same height of eliminate urban and rural dual system , solve urban house prices high, pollution huge and other concrete problems, build countries with beautiful mountains and rivers, build urban and rural unified education, health care, housing security system, attract urban population to the countryside "reverse flow", can eliminate the gap between urban and rural areas, and also can solve the city high house prices, high pollution.

The second is to formulate incentive policy, promote develop open education in rural areas. Although mobile phone users dramatically increase in our country's, but corresponding cell phone use cost especially the cost of internet service fee has been not much dropped, in China urban and rural areas, the internet cost and income ratio is still higher than many developed countries in the world, there are a lot of price cut space. The nation should introduce policy, such as use mobile phones access open education site to learn then the cost of Internet service fee will be free, or give some Internet traffic for free, or online learning to achieve a certain time will giving intelligent mobile phone as present, or direct subsidies Internet learning cost, etc., all thee can promote the development of open education, and gradually reduce urban and rural education gap, realize the education fair. 


\section{B. Adapt to the new situation of development. There is no} time to delay the change to open and distance education itself.

One is to strengthen the platform development and upgrade. At the early stage, to development the open education platform is just in order to meet the degree education, its content and resources has significant limitations, if fusion the degree education and non-academic education, basic education, skills training and other kinds of education into one platform, we need to upgrade platform.

The second is widening the object of education. Open education object is not only degree educators, they may learners for a specific skills, a consultant in the process of agricultural production, people need help in a life problem and so on, open education need to implement a greater range of "open", to include more education group.

The third is to from the organization of the teaching content, teaching method, teaching resource design and other links to reform, make it more suitable for intelligent mobile phone, tablet PC, and other mobile devices to use, use and operation more convenient and simple, so as to adapt to the needs of the development of information, to adapt the new situation of the rural open education demands.

\section{Changing concept, look open learning as a kind of way} of life of urban and rural residents

Due to the influence of feudal farming society for thousands of years, the pedagogue's utilitarian is very strong in our country, such as "the book has the gold room", "the book has sexy lady" etc., together with there are the less chance for bottom flow up in feudal social, and by learning to participate in the imperial examination is the only way for a grassroots people to change their status. In addition, China's ancient look reading and study as a "bitter" things, such as "pore over one's books by the light of a candle", "the head hang beam the awl stab" story, until today is still a lot of teacher praise highly. Therefore, we must change ideas, set up the concept learning is the pursuit of a better life, and learning is an important part of life. Along with the urban and rural people's living standards gradually improved, the continuous improvement of the social security system, the utilitarian of study will gradually blurred, gradually on the path of "return uncut jade to return true”.

Open education not only can eliminate the gap of urban and rural education ,promote education fair, still can further improve the level of rural residents, and promote the culture of spiritual civilization construction in the countryside, improve and enhance their quality of life.

\section{REFERENCES:}

[1] QianTong, GuLiLin, JiMing. New urbanization to the "new" in where? http://news.xinhuanet.com/18cpcnc/2012-11/11/c_113660437.htm. (2013.1.8)
[2] Introduction to Modern Open and Distance Education [DB/OL]. http://www.lytvu.com/www/lyycxxzx/20091201/n591674.html. (2013.1.9) [3] The central RTUV development planning office. 2010 national TV university education basic statistics bulletin [J]. China's Remote Education,2010,(3):72-73.

[4] Baidu library. From the historical point of view China's current the household registration system and its reform direction[DB/OL].

http://wenku.baidu.com/view/23af8f28ed630b1c59eeb54f.html.(2013.1.23

[5] Zhang Wei. Shaanxi urban per capita disposable income growth break twenty thousand in the fourth [DB/OL].

http://news.hsw.cn/system/2013/01/22/051592597.shtml.(2013.1.23)

[6] The national bureau of statistics survey corps in Shaanxi province. 2006-2011 provinces (cities, districts) per capita net income of farmers increase sort.

http://www.nbs-sosn.cn/index.aspx infoid $=591$ \&language $=$ cn\&lanmuid $=1$ 3\&menuid=3\&type=articleinfo.(2013.1.23)

[7] [8] DuRuiYun. To our country household register system reform of new thinking [DB/OL].

http://blog.sina.com.cn/s/blog_5c4755900100f7yt.html.(2013.1.23)

[9] The domestic Internet users over 550 million [DB/OL].

http://www.cww.net.cn/news/html/2013/1/4/201314114634453.htm.(2013. 1.25)

[10] Yuan guiren. Education fair is the most fundamental and most important social fair [DB/OL].

http://learning.sohu.com/20120618/n345884710.shtml.(2013.1.25) 